\title{
THE ASSOCIATION BETWEEN KNOWLEDGE ABOUT HIV/AIDS AMONG ADOLESCENTS AND STIGMA TOWARDS PEOPLE LIVING WITH HIV/AIDS IN INDONESIA
}

\author{
Rizka Dita Hidayati, Dewi Rokhanawati \\ Universitas Aisyiyah Yogyakarta
}

\begin{abstract}
Background: The stigma against HIV/AIDS leads to suspicion, negative attitude, and rejection towards people living with HIV/AIDS (PLWH) and their communities. The stigma that occurs in adolescents may be influenced by various factors, one of which is knowledge of HIV/AIDS. This study aimed to determine the association between knowledge about HIV/AIDS among adolescents and stigma towards PLWH in Indonesia.

Subjects and Method: This was an analytic observational study with a crosssectional design. A sample of 10,437 adolescents was selected for this study. The dependent variable was stigma towards PLWH. The independent variable was knowledge about HIV/AIDS. The data were taken from Indonesia Demographic and Health Survey (SDKI) year 2012. The data were analyzed by chi square test.

Results: There was an association between knowledge about HIV/AIDS in adolescents and stigma towards PLWH. Stigma towards PLWH increased with a lack of knowledge about HIV/AIDS among adolescents $(\mathrm{OR}=2.66 ; 95 \% \mathrm{CI}=2.24$ to $3.15 ; \mathrm{p}<0.001$ ).
\end{abstract}

Conclusion: A lack of knowledge about HIV/AIDS among adolescents is associated with an increase in stigma towards PLWH.

Keywords: stigma, knowledge, HIV/IDS, PLWH, adolescent

\section{Correspondence:}

Dewi Rokhanawati. Universitas 'Aisyiyah Yogyakarta, Jl. Ring Road Barat No. 63, Nogotirto, Gamping, Sleman District, Yogyakarta 55592.

Email: dewik.2011@gmail.com 